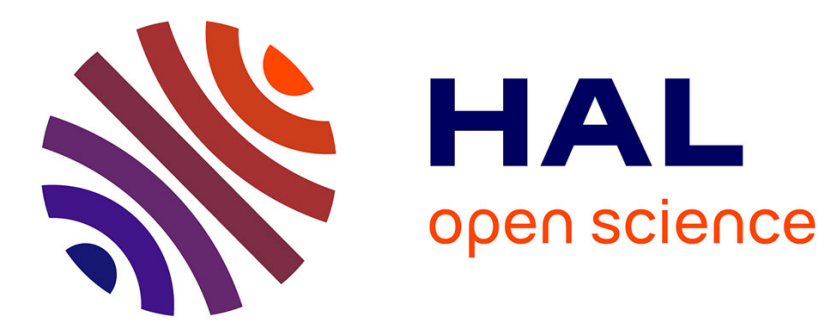

\title{
A critical analysis of the evidence for sexual division of tasks in the European Upper Paleolithic.
}

\author{
Sophie A. de Beaune
}

\section{To cite this version:}

Sophie A. de Beaune. A critical analysis of the evidence for sexual division of tasks in the European Upper Paleolithic.. K. A. Overmann et F. L. Coolidge. Squeezing Minds from Stones: Cognitive Archaeology \& the Evolution of the Human Mind., Oxford University Press, p. 376-405, 2019. halshs02780243

\section{HAL Id: halshs-02780243 \\ https://shs.hal.science/halshs-02780243}

Submitted on 11 Jun 2020

HAL is a multi-disciplinary open access archive for the deposit and dissemination of scientific research documents, whether they are published or not. The documents may come from teaching and research institutions in France or abroad, or from public or private research centers.
L'archive ouverte pluridisciplinaire HAL, est destinée au dépôt et à la diffusion de documents scientifiques de niveau recherche, publiés ou non, émanant des établissements d'enseignement et de recherche français ou étrangers, des laboratoires publics ou privés. 
KARENLEIGH A. OVERMANN \& FREDERICK L. COOLIDGE

S QUEEZ I N G

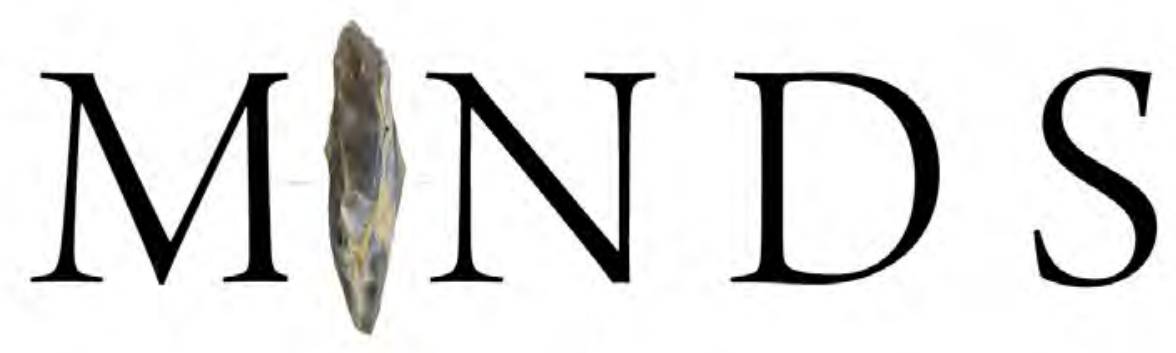

F R O M

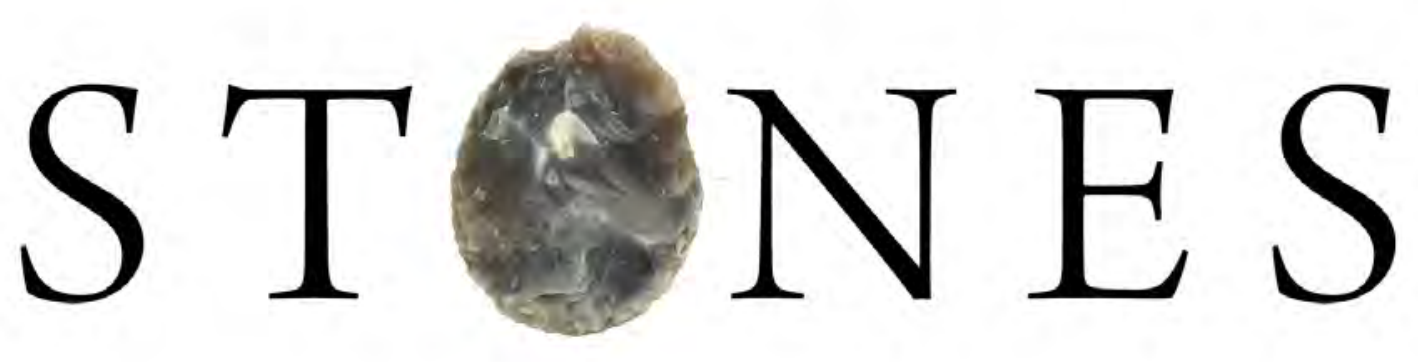

\section{Cognitive Archaeology of the \\ Evolution of the Human Mind}




\title{
A CRITICAL ANALYSIS OF THE EVIDENCE FOR SEXUAL DIVISION OF TASKS IN THE EUROPEAN UPPER PALEOLITHIC
}

\author{
Sophie A. de Beaune
}

\section{INTRODUCTION}

Currently, we are able to provide an accurate picture of the lifeways of human groups in Europe during the Upper Paleolithic (UP), based on analyses and interpretations of remains left behind. To facilitate the analysis of activities we can break down their different stages, which are represented by tasks. For example, the activity of hide working includes several distinct tasks - flesh removal, tanning, and currying. The distribution of tasks within a group is directly linked to its social organization, since even if the entire group can participate in a single activity, the task can vary for each individual. The tasks, in turn, can be analyzed and subdivided into technical actions and gestures; however, we will not address these subdivisions in detail here (see de Beaune, 2000).

Despite our reliable knowledge of the material life of these populations, we know very little about the distribution of tasks according to age and sex. Division of labor, by gender or simply by individual, is a central component of just about all human societies. It is also a precursor to development of social inequality and conflict. While researchers have periodically addressed these topics for the Paleolithic, no major synthesis has been provided for some time. Moreover, we will see here that many interpretations are based on naïve or inaccurate stereotypes. Three types of explanations have been proposed:

(1) Simple suppositions based on ethnographic comparisons, particularly concerning the sexual division of tasks, through reference to what is most often observed among living or recent populations

(2) Explanations based on indirect archaeological evidence

(3) Explanations based on direct evidence, which, as we will see, are rare and difficult to interpret

The analysis in this chapter is focused on the UP and its margins because the division of tasks for the very early periods of the Paleolithic concern pre-human species for which we have very little information. It is possible that the social organization of the first representatives of the genus Homo and the australopithecines was closer to that of the modern great apes than to that of $H$. sapiens. In addition, it is generally accepted that European UP sites were occupied by H. sapiens, though this is sometimes 
debated for the earliest sites (e.g., archaic Aurignacian); some researchers attribute it to Neandertals. This is not highly significant relative to the ideas presented here, since lifeways do not appear to have changed considerably from 40,000 to $10,000 \mathrm{BC}$.

Nevertheless, it is of interest to consider what happened before the UP (i.e., during the Lower and the Middle Paleolithic [LP/MP]) or just after (during the Epipaleolithic and the Mesolithic periods) if the available data can provide insight regarding what happened during the UP.

I am aware that gender archaeology is a common topic in Anglo-American archaeology. The volume of literature on it is tremendous, so for my discussion here I have selected only the most relevant references, without claiming completeness (Bolger, 2013). ${ }^{1}$ Here I consider that, even when discussing male and female tasks, it is possible that technical specialization is not related only to sex.

\section{"SIMPLE" SUPPOSITIONS BASED ON ETHNOGRAPHIC COMPARISONS}

It is generally accepted that, until recently, current hunting and gathering peoplesthe Arctic Inuit, Aboriginal Australians, Kalahari San, and similar groups-lived in relatively small groups, without centralized authority, standing armies, or bureaucratic systems (Ingold, 2004; Lee \& Daly, 2004). These societies were relatively egalitarian and did not include members whose only task was to produce a specific type of object (Woodburn, 1982). Morgan's evolutionist ideas inspired Marx and Engels to characterize the original state of human society as one of "primitive communism" (Lee, 1979, 1988; Testart, 1985). The "communism" of hunter-gatherer societies was embedded in relations of immediate kinship, essentially "familistic" (Service, 1966), what Marshall Sahlins called the "domestic mode of production" (Sahlins, 1972). Of course, some authors distinguish between simple and complex hunter-gatherers, arguing that not all the hunters and gatherers lived in small mobile bands; some of them lived in semisedentary settlements, had chiefs, and stored some resources (Hayden, 2013; Price \& Brown, 1985; Testart, 1982, 2005, 2012).

Regarding the equality of UP societies, several authors have shown that the term equality needs qualification and that nascent forms of social hierarchy existed during this period in some ecological conditions, such as in the southwest of France or the central Russian plain (Conkey, 1985; Mellars, 1985; Soffer, 1985). Brian Hayden has widely developed this idea, comparing some UP regional groups with northwestern North America (Hayden, 2001, 2013). I will come back to this point later in the chapter.

The majority of researchers nonetheless suppose that, as in extant or recent "simple" hunter-gatherer societies, Paleolithic populations must have had some distribution of tasks, which in its simplest form consisted of a sexual division of labor

\footnotetext{
1 I will not address here the thesis that there are cognitive differences between men and women (e.g., that women might have more gray matter (Luders, Gaser, Narr, \& Toga, 2009), emphasize better (Baron-Cohen, Knickmeyer, \& Belmonte, 2005), or be better at remembering the locations of objects (Eals \& Silverman, 1994), relative to men. Ethnographical counter-examples, as well as our daily life experience, are enough to show that these competences depend on social context.
} 
(Lee, 1979, 1982; Testart, 1982). Most tasks were gendered, and big-game collective hunting appears to have been in general, though not exclusively, a male task (Knüsel \& Smith, 2013; Murdock \& Provost, 1973; Testart, 1986). According to Lee (1979), women in hunter-gatherer societies contribute to most of the family's daily calories through gathering and sharing activities, but this is a somewhat oversimplified generalization based on a single case (i.e., the Kalahari San). Contributions to diet from different sources of food and by different genders vary tremendously across the globe. We would expect a very different dietary mix in glacial Europe than in Holocene southern Africa. Furthermore, in an archaeological context, the organic objects traditionally associated with female activities (e.g., digging sticks, skin bags, etc.) would leave no trace. This may be the reason why the "man-the-hunter" model was widely promoted after the 1965 anthropological symposium of that name, organized by Irven DeVore and Richard Lee, as reflected in the following quotes: "Hunting is so universal and is so consistently a male activity that it must have been a basic part of the early cultural adaptation, even if it provided only a modest proportion of the food supplies"; "It is also likely that early woman would not have remained idle during the Pleistocene and that plant foods, which are so important in the diet of inland hunter-gatherers today, would have played a similar role in the diet of early peoples" (Lee \& DeVore, 1968b). Thus hunting is viewed as central to explaining human evolution (Tiger, 1969; Washburn \& Lancaster, 1968; Zihlman, 2013). Gender and the importance of women's work was a topic much discussed during the conference "Man the Hunter" and after the publication of the proceedings (Lee \& Daly, 2004; Lee \& DeVore, 1968a; Sterling, 2014). The gathering or "woman the gatherer" hypothesis was developed as a corrective to the omission of women and women's activities in such reconstructions (Dahlberg, 1981; Zihlman, 1998).

In any case, the trope of man $=$ tool- maker $=$ hunter versus woman $=$ mother $=$ gath erer, which is highly speculative when the social organization of UP populations is considered, has been widely accepted for over a century (Clottes, 2015; Guthrie, 1984, 2005). Following the data published in the Ethnographic Atlas (Murdock, 1967), stone-working was basically deemed a male activity (Murdock \& Provost, 1973), ${ }^{2}$ and women were implicitly identified with gathering plant resources and "soft" technologies such as hide working and the production of clothes, textiles, cords, lines, and (for later prehistory) ceramics (Finlay, 2013; Zihlman, 2013). Among extant hunter-gatherer populations, all members of the community participate in daily tasks depending on their mobility. The elderly and the women usually gather and hunt small animals near the camp, while the young mothers take care of the younger children. A schematic engraving found at the Magdalenian Gönnersdorf site, representing a woman who appears to be carrying a baby on her back, tends to support the idea that the same was true during the UP (Bosinski, 2007; Bosinski \& Fischer, 1974). It is thus assumed that children collected firewood near the camp, helped women gather vegetal resources, carried water, and collected the small animals captured in traps. Adult

2 In 1962, George Murdock founded Ethnology: An International Journal of Cultural and Social Anthropology, published by the University of Pittsburgh, in which he published installments of his Ethnographic Atlas between 1962 and 1980-a data set eventually containing 1,167 cultures coded for over 100 variables. 
men hunted large animals and traveled further to acquire specific resources that were not available near the camp. This scenario was commonly spread in popular literature, cinema, and comics, as can be seen, for instance, in Zdenek Burian's pictures and countless other reconstructions of Paleolithic life (Gifford-Gonzalez, 1993).

Following the first interpretations from the beginning of the twentieth century (Bégouën, 1924, 1939; Breuil, 1952; Reinach, 1903), Guthrie argued that Paleolithic art was a hunter's art, and as a consequence of the above-mentioned schematic vision of gendered activities, he came to the conclusion that it was a male activity (Guthrie, 1984, 2005). Today's researchers have consistently demonstrated that the animals most often represented in Paleolithic caves are among the ones least frequently consumed as food (Delporte, 1990; Iakovleva \& Pinçon, 1997). Even if confirmed that the pictured animals were hunted animals, it does not follow that this was a male activity. In a provocative manner, Guthrie likened female figurines to the images of women in Playboy and suggested that the artists were men with erotic preoccupations. Of course, specialists of Paleolithic art criticized this simplistic interpretation, which underestimated the cultural context of UP art (Hays-Gilpin, 2004; White, 2006).

The ethnographic basis for these reconstructions is far from evident, however. It is founded on the supposition that there are universally male activities (e.g., large-animal hunting) and universally female activities (small-animal hunting, gathering, collecting) (Endicott, 2004). Some scholars have gone as far as to attempt to identify universal behavioral laws. They argue that there are features of human society that are universal or nearly so (Brown, 1991), and that the broad division of labor into hunters and gatherers by sex is one of these universals. Then the fact that such disparate societies should share these traits suggests that they have deep evolutionary ancestry (Codding, Bird, \& Bird, 2011; Kaplan, Hill, Lancaster, \& Hurtado, 2000; Marlowe, 2007). According to Alain Testart (1986), some tasks appear to have never been performed by women, such as killing an animal with a cutting weapon, but there are two arguments against this hypothesis. First, the theory that women could not draw blood in hunter-gatherer societies assumes that these societies were specific entities that can be distinguished from other types of societies. What we define as hunter-gather societies, however, results from an artificial classification made by Western researchers, who distinguish them only by the absence of agriculture. The absence of some elements, however, is a criterion that is clearly insufficient to define a society. This category of societies that survive through hunting and gathering (what about fishing?) is in reality very heterogeneous. François Sigaut (2009) has made the analogy between this classification and the one made by zoologists between vertebrates and invertebrates, recognized as insufficient as early as the late eighteenth century when scientists realized that the absence of vertebrates was not sufficient to define a homogeneous group. Furthermore, Testart's thesis implies that, by some miracle, the sexual division of labor in nonagricultural societies was governed by the same ideological principles from Australia to the Kalahari, and from the Amazon to Siberia. So far, nobody has demonstrated the existence of "universals" in human societies (Lenclud, 2013). On the contrary, Robert L. Kelly (1995) has documented the tremendous diversity in hunting and gathering societies around the world, and Susan Kent (1996) has observed similar diversity in Africa. Testart himself had to recognize that there are some exceptions to the supposed "law," following which women could not draw blood: Agta women regularly hunt with machetes or bows and arrows (Estioko-Griffin \& Griffin, 1981; 
Hayden, 1992; Testart, 1986). Besides the Agta, there are many cases of women acting as hunters, whether temporarily or permanently, especially in high-latitude locations where most of the diet comes from hunted foods. Testart's hypothesis also ignores the documented participation of female Native American hunter-gatherers in the mistreatment of captives (Donohoe, 2009). This "blood ideology" seems to be more that of Testart than of hunter-gatherers.

In addition, the ethnographic data must be contextualized, since some domestic activities, such as tending fires, working hides or wood, and making rope, are realized by both men and women, depending on the society, as a function of the global distribution of activities in groups. Many hunter-gatherer men gather vegetable foods when the need or opportunity arises, even if it is not a usual daily activity. In most foraging societies, if a man's primary task is hunting, women often hunt as well (Endicott, 2004). Ethnographically, women often play an important role in the acquisition of animal protein, but they serve predominantly as trappers and as beaters to drive game and perform supporting roles as butchers, participants in drives, and supernatural support. Hunting, after all, is more than the simple act of killing an animal, and the ethnographic accounts drawn by Wadley (1998) demonstrate the wide variety of ancillary activities considered by various groups as part of hunting, from sewing to meat sharing.

Stone flaking, by contrast, appears to be practiced by men in nearly all of the societies in which it is known, although there are exceptions (Casey, 1998; Kelly, 1995; Sassaman, 1998). For instance, women flaking stone is found among the Konso of South Ethiopia, the Arawe of New-Guinea, and the Tiwi and the Jerramungup of North and Western Australia (Arthur, 2010; Bird, 1993; Goodale, 1971; Weedman, 2006). Moreover, if stone flaking appears as a mainly male activity, it might be because the ethnographic data are biased: The few observations we have were made by male observers, often in societies with strong gendered division in the use of space, and almost always in places where people no longer relied on chipped stone, as highlighted by Kathryn Weedman's (2005) work on hide workers in Ethiopia. Linda Owen (2005) points out that comparative studies of male and female activities in extant or recent hunter-gatherer societies have contributed to creating stereotypes of their roles by reducing the number of variables in order to simplify statistical analyses. Today, a more critical attitude toward the use of ethnographic analogy in archaeological interpretation is expressed by many researchers (Bolger, 2013).

However, it might be the case in many societies, even when women and men ostensibly perform the "same" tasks, that distinctions are maintained in technology, materials, type of product, and/or consumers. For instance-and Testart (1986) is correct on this point-men and women's hunting techniques and weapons often (but not always) differ (Endicott, 2004). In parts of West Africa, women and men use different kinds of looms and weave distinct types of cloth that are explicitly called "women's cloth" and "men's cloth" (Kent, 1971; Kriger, 2006). Among the Wola in Highland Papua New Guinea, on the few occasions women knap, they use a bipolar technique that men consider inappropriate when they knap (Sillitoe \& Hardy, 2003). The ethnohistorical evidence from Sydney Harbor (Australia) indicates that both men and women fish from shore or in canoes. However, men invariably used a two- or fourpronged, barbed fishing spear, whereas women used hook and line, with a shell fishhook that they manufacture themselves and vegetable fiber line (McDonald, 1992). 
Also, all members of a group may participate in the same activity but do not perform the same tasks. Hunting by driving large herds of herbivores, for example, is an activity that requires many participants and solicits all members of the group, but not to perform the same task. In Mbuti bow-and-arrow hunts, women act as beaters to drive game within range of the armed men (Turnbull, 1965). Netsilik women and children help men with seal hunting, and everyone fishes (Balikci, 1970). It is also possible that the different phases of a manufacturing sequence might not all be carried out by the same individuals. In textile production, in some cases, different tasks within the production sequence are performed by different genders. For example, in royal textile workshops of eighteenth-century Benin, men spun and women wove (Kriger, 2006). At times, the distinctions in gendered task assignments are so subtle that the ethnographer might miss them (Costin, 2013). In the Paleolithic, animal carcasses, for example, might have been cut into pieces by some individuals, while the meat was removed by others responsible for preparing meals.

Furthermore, even when an archaeological site appears to yield indices of task specialization, we cannot presume the identities of those who performed these tasks. For instance, when Kenneth Sassaman (1998) claims - without specific evidence-that in the Eastern Woodlands of North America, men hunted game using a stone tool technology, namely hafted bifaces, distinct from that made and used by women for other activities, he seems to apply stereotypes to archaeological data. It is not necessarily one sex or the other, but perhaps a specific group, as is the case in some modern hunting societies, that stores animal products, and a particular group is responsible for providing the meat reserves for the entire community. In any case, such indices are difficult to observe in archaeological data: The absence of an activity at a site does not prove anything, since it could have been performed in a part of the site that was not excavated or, in the case of nomadic groups practicing seasonal movements, in a different camp or at a different time of year.

\section{EXPLANATIONS BASED ON INDIRECT ARCHAEOLOGICAL EVIDENCE}

Several authors have attempted to model the social organization of UP populations on the basis of indirect data. Gendered tasks are not directly visible, but some archaeological remains are interpreted to demonstrate a sexual division of tasks. Let us examine a few of these attempts.

\section{Emergence of Task Diversification}

For Steven L. Kuhn and Mary C. Stiner (2006), the sexual division of tasks among $H$. sapiens is linked with dietary diversification and, in particular, the emergence of small-prey hunting and gathering. These authors start from the classic hypothesis that men hunted large prey, while the tasks of women and children were limited to hunting small prey and gathering. To support their demonstration, they compared the diet of anatomically modern humans (AMH) and Neandertals.

According to Kuhn and Stiner, Neandertals hunted only large prey. However, this activity would have required the cooperation of all members of the group to secure a sufficient amount of meat to feed everyone. In contrast, they portray UP 
AMH groups as having had a much more pronounced sexual division of labor, which enabled women to exploit plant resources, thus widening the subsistence breadth and adapting groups more effectively to the environment and resulting in higher population densities (Kuhn \& Stiner, 2006). Modern counter-examples do exist, such as that of the Inuits, who had a diet consisting only of meat and for whom the sexual division of tasks was as strong as among other groups: The women worked hides, made clothes, cooked, and tended fires, while the men constructed dwellings and hunted and fished (Hayden, 2012).

Although the idea that labor division appeared at the same time as task diversification (and thus resource diversification) is interesting, it is not certain that this "innovation" really occurred between the MP and UP. We have recently learned that the Neandertal diet was more diverse than previously thought. Use-wear analyses of stone tools and the organic residues on their surfaces have shown that Neandertals hunted small prey and fished. Moreover, these analyses were made on artifacts from sites distant enough from each other-in France (Payre, Ardèche), Spain (Bolomor Cave), and Italy (Fumane) - to eliminate the hypothesis that this could be a local phenomenon (Hardy \& Moncel, 2011). Other analyses of the teeth of Neandertals from Spy (Belgium) and Shanidar (Iraq) showed that they consumed a variety of vegetal resources (Henry, Brooks, \& Piperno, 2010). It therefore appears that the diets of AMH and Neandertals were not very different from each other. The question of how important such foods were to the Neandertal diet still remains. Was it as relatively important as it is among the San, who eat some meat but also a lot of fruits and vegetables? Or was it as episodic as it is among the Inuit, who eat much more meat than vegetables? The available Neandertal data are still too scattered to allow us to answer with certainty. The interesting fact is that Neandertals could and did use vegetable foods and quick, small game, as well as big-game meat, whatever the proportions might have been.

Furthermore, we now clearly know that some tasks, such as the manufacturing of handaxes, required a high skill level and thus would have been associated with some form of specialization already in the MP. I will come back to this point later.

As seen from this discussion, the field of archaeology has changed dramatically in the past two decades, as women archaeologists have challenged their male colleagues' exclusive focus on hard artifacts such as spear points rather than tougher-to-find evidence of women's work. Through the study of the perishable artifacts such as basketry, cordage, and weaving, Jim Adovasio and Olga Soffer (Adovasio, Soffer, \& Page, 2007; Soffer, Adovasio, \& Hyland, 2002) argue that, even if women did not participate in hunting activities, they invented all kinds of critical materials, including the clothing necessary for life in colder climates, the ropes used to make the rafts that enabled longdistance travel by water, and the nets used for communal hunting. Even more importantly, women played a central role in the development of language and social life-in short, in our becoming human. Even if we don't know exactly who did what, Adovasio and Soffer show that activities were much more diversified than previously inferred from artifacts of bone, antler, ivory, and stone.

\section{Activity Zone Locations in Occupation Sites}

The presence of zones reserved for specific activities in occupation sites has been interpreted as a topographic reflection of a division of gendered tasks. This type of 
study is based on the hypothesis that some artifacts reflect activities associated with a particular sex. Weapons, tools, and flaking by-products would thus be associated with hunting, butchery, and stone flaking, which are strictly men's tasks, while fireplaces, needles, and scrapers would reflect women's tasks like hide working and food preparation. Such assumptions have been largely discounted by Linda Owen (2005), who showed that these stereotypes are simplistic (and sexist). It is in fact possible for a location to be dedicated to a specific activity while still being frequented by both men and women.

Let us examine a few examples from the literature. At Mal'ta in Siberia, Mikhail Gerasimov thought that he could distinguish two sectors of the site. One, which he interpreted as masculine, was associated with bifaces, bone daggers, and bird figurines, while the other, interpreted as feminine, contained scrapers, needles, awls, necklaces, and female figurines (Gerasimov, 1958, cited by Baffier, Julien, \& Karlin, 1981). We can see that this interpretation made in the late 1950s was highly ethnocentric.

Another more recent case concerns the Epipaleolithic site of Ohalo II, located on the banks of Lake Tiberias (or the Sea of Galilee) in Israel. This site, dated to between 23,000 and 22,000 BC (calibrated), was occupied by hunter-gatherer populations with no agriculture or domesticated animals. Nonetheless, the site contains at least 90,000 remains from 142 plant species that were consumed or used in their wild state. In particular, 19,000 grass seeds were well preserved because they were charred in fireplaces before the site was submerged by the lake, thus protecting them. Among these grasses, the ancient wild ancestors of grains, in particular emmer wheat and barley, are present (Nadel et al., 2004).

A basalt stone found in one of the huts (number 1) appears to have served as a grindstone to process these grains, a hypothesis supported by the presence of 150 grain fragments encrusted in its upper face, 127 of which belong to the barley and wheat families (Hordeum, Triticum, Aegilops). Other grains were scattered around the stone. In addition, an alignment of stones covered with ash suggests the presence of ovens. From here, it is not a giant leap to imagine that an ancestor of bread made from wild grains was cooked here (Piperno, Weiss, Holst, \& Nadel, 2004).

Meanwhile, Dani Nadel and Ehud Weiss (Weiss, Kislev, Simchoni, Nadel, \& Tschauner, 2008) recognized that this hut had two very distinct activity zones separated by a passage area between them. One zone in the back of the northern part of the hut appears to have been dimly lit; it contained the grindstone and the scattered wild cereal grains. The second zone, with the stone flaking by-products, was probably better lit, since it was located near the entrance. The authors suggest that the first zone, linked to food preparation, was associated with women, while the second zone, dedicated to tool and weapon manufacturing, would have been associated with men. Although this interpretation is tempting, we must remain cautious and cannot eliminate the hypothesis of a physical separation of tasks related to hygienic concerns rather than gendered division.

Similarly, Françoise Audouze (2010) has suggested that the distribution of backed bladelets (here used only as projectile weapon elements) around fireplaces at the Magdalenian site of Verberie (Oise, France) could correspond to a male activity zone, while the presence of scrapers furthest from the fireplaces could indicate a hide-working zone and thus be associated with women. She nonetheless tempers this interpretation, noting that there could be technical reasons for such a spatial 
distribution: Weapons could have been manufactured near the fireplaces because heat is needed to melt the adhesives, while hide working must be done far from the fire to avoid the risk of hides being damaged by flying sparks (Audouze \& Beyries, 2007). We must thus be wary of assuming that the position of such activity zones is linked to social norms.

At Pincevent, Grégory Debout (2007) went even further: He identified a zone that appeared to be dedicated to working hide with characteristic flint tools, the presence of ochre, and a one-meter ${ }^{2}$ accumulation of ash that might correspond to a drying zone. Three skill levels in blade manufacturing were also distinguished at this site. The most successful productions appear to have been carried outed by true experts, others by flakers with an average skill level (perhaps apprentices in training). Finally, the worst-quality productions were perhaps the work of young individuals in the very early stages of their apprenticeship. However, these poor-quality productions are located near the area where there is evidence for hide working-leading to the interpretation that this was a female activity zone with children playing and imitating the adults nearby.

The problem raised by these different interpretations is that they are based on the suppositions described earlier concerning the distribution of tasks among men and women in non-industrial societies. We can clearly see, however, that the specialization of space does not necessarily reflect that of its occupants. This is why some authors have begun to look for more direct evidence of task distribution.

\section{EXPLANATIONS BASED ON DIRECT EVIDENCE}

One parameter is sufficiently visible in archaeological contexts to allow the identification of technical specialization: skill level. It has been used to evaluate the degree of competence of individuals and therefore their possible specialization. Let us see if this evidence tells us something about task gendering.

\section{Evidence for Different Skill Levels}

Theoretically, specialization can be identified on the basis of technical criteria, such as the different skill levels required to carry out various different tasks or the standardization of certain products. The second argument can be eliminated right away because standardization can result both from the work of a specialist or a workshop or from strict technical or social constraints imposed by a single operational procedure (Le Dosseur, 2005).

Archeological experiments to knap stones indicate that high levels of expertise are acquired over long periods of training and through processes of interactive learning under the supervision of a skilled practitioner (Eren, Bradley, \& Sampson, 2011). Such experiments give us an idea of the effort involved in obtaining knapping expertise that would enable a knapper to efficiently and regularly produce standardized and elaborate forms.

The presences of different skill levels has been confirmed at Étiolles and Pincevent, where Nicole Pigeot and Monique Olive (Olive \& Morgenstern, 2004; Pigeot, 1987) demonstrated that the knappers of Magdalenian artifacts did not all have the same stone-flaking talents. The proficient flakers were able to manufacture long 
blades and tools of an excellent quality. Other individuals had a more mediocre skill level that was nonetheless sufficient to manufacture the occasional tools necessary for daily activities. Flakes that were probably never used were also found, likely made by young children, who had even less skill. It was also proposed that beginning flakers, probably children given their low level of skill, were also present at Verberie (Janny, 2010). It is easy to imagine young children observing the work of adults and imprinting the movements and actions that had to be accomplished. They would then imitate these actions with their clumsy hands, while sometimes getting advice or being reprimanded. In any case, the stability of stone tools over thousands of years indicates that knowledge and know-how were transmitted from one generation to the next. We once again encounter the reconstruction of Gregory Debout here, though without any allegation of the sexual identity of the actor.

We do find this allegation in Nicole Pigeot's (2010) study of blade manufacturing at Étiolles. In addition to two skill levels, perhaps corresponding to novices and proficient flakers, she argues that she was able to detect productions that were well mastered but simplified. This intermediary category, which she attributes to adults, could be associated with women who occasionally flaked to satisfy immediate needs, but for whom this was not their primary activity. Why women and not some not yet fully training teenagers? She does not answer this question. She implicitly links female lithic production to a more expedient technical strategy (Bamforth \& Finlay, 2008). Women are still seen by many archaeologists as stone-tool users, not makers; and stoneworkers as fathers teaching their sons to knap (Johansen \& Stapert, 2008). In the same vein, Schick and Clark (2003) suggest that small flakes in East African Acheulean sites could have been made by elderly, female, or juvenile individuals, who might have needed to have such material ready to hand in case they opportunistically encountered scavenging occasions while gathering, whereas localities with large bifaces made from materials obtained from distant sources reflected planned hunting by males.

Peter Hiscock (2014) claims that making stone artifacts requires highly skilled individuals who have been taught and have practiced for extensive periods, something that occurred as early as the LP. These specialized competencies were not limited to knapping itself but also included procuring material, which demands an understanding of the inorganic materials being worked and an ability to track geological resources across the landscape. Competency and expertise could develop specialization through forms of social learning and teaching over multiples generations, and even could stimulate competition between knappers. Peter Hiscock does not hesitate to talk of "craft specialization in which a fraction of the group focused their energies on knapping" in the Oldowan and Acheulean industries (Hiscock, 2014).

Jacques Pelegrin (2007) does not agree with the hypothesis of true flaking specialists who would have been the only ones able to fulfill a function essential to the community's survival. This is why he distinguishes between a "Paleolithic expert" and a "Neolithic specialist." The former had a definite skill and was able to carry out specific technical operations but did so in a context that remained within the range of ordinary productions, while the latter, who had exceptional skills, made only certain types of products to fulfill an external demand. The pertinence of this distinction based on competence levels is debatable since we do know that specialization does not always imply an exceptional skill level. This is the case, for example, for Neolithic pottery, whose realization required only an average skill level but which nonetheless 
was manufactured in a context of specialization (Gomart \& Burnez-Lanotte, 2012; Vieugué, 2012). One can be a specialist and not be very skilled, and activities requiring little skill can be practiced by specialists (e.g., many traditional caste occupations in India). Specialization has a lot to do with the time demands of an activity and whether it interferes with other activities. It may also be an option for individuals who are unable to participate in other activities.

On the gender of knappers, it was commonly accepted that it was a male activity, following the values attributed to male and female roles until the "Man The Hunter" conference in 1965 (Lee \& DeVore, 1968a). Another argument regarding the repartition of tasks by sex appeared in the Ethnographic Atlas (Murdock \& Provost, 1973). Stone-working was identified as a male activity in 67 societies and in only 6 as a male or female activity. Despite many biases and flawed calculations, this evidence is still used uncritically by many researchers. In fact, stone tools made and used by women are known from a diverse range of ethnographic contexts, as we saw earlier (Finlay, 2013). But it is very difficult to extrapolate from this the sex of UP knappers.

\section{Evidence for Specialization}

What then do these different skill levels indicate? Are we looking at a simple division of labor according to age and sex with domestic production, or a true specialization in the sense that the activity was performed by only a limited number of individuals (or groups) who redistributed their products among a larger community? This type of specialization is even more difficult to identify as it may concern only part of the chaine opératoire. Gaëlle Le Dosseur (2005, p. 127) proposes addressing the question by evaluating the time required to carry out certain activities, which could sometimes be long enough to suggest a "full-time" activity, at least on specific occasions. This is the case, for example, for the manufacturing of bone beads, hundreds of which have been found at several Natufian sites. How can we explain the approximately 13,300 ivory beads found in the three graves at Sunghir (Russia), dated between 25,000 and 27,500 ${ }^{14} \mathrm{C}$ before present (BP), and which would have required 30 minutes per bead, or 3.33 years at 40 hours per week—totaling 6,650 hours of work (Trinkaus, Buzhilova, Mednikova, \& Dobrovolskaya, 2015)! After various experimentations, Randall White (1999) has even suggested that each bead required 45 minutes, which implies many more hours of work. It is difficult in this case not to imagine an artisan specialized in the manufacturing of personal ornaments. But the vast amount of time represented by the Sunghir burial beads could also represent part-time (seasonal or evening) work by many people. Traditional folk are rarely idle-when they are not doing things related directly to survival, they are often busy making and mending. Without knowing the number of individuals involved in the activity, however, it is impossible to evaluate the amount of time devoted to it, relative to food procurement activities, let alone whether the activity required dedicated specialists or was gendered.

We can also consider the possibility of specialization when we see that a specific raw material was used far from the place where it was collected and/or worked-though we must be certain that these different tasks were not performed by the same people who traveled far away to procure raw materials that they then worked and brought back to their usual residence site. This supposes that we are able to show the existence of exchange networks organized by individuals other than the users of the final 
products. Such networks and the specialization that they imply have been identified in the Early Neolithic. For example, the circulation of obsidians from central and eastern Anatolia over more than $900 \mathrm{~km}$ toward the Near East by land and toward Cyprus by sea indicates specialized productions that were introduced into settlements in the form of finished objects (Astruc, 2005). For the UP, François Bon (2005) sought to learn whether the same could have occurred in an earlier period by analyzing the lithic objects found at several occupation sites in southwestern France and dated to the Early Aurignacian period. The raw materials from which these objects were made had both local and distant origins. We could consider the possibility of task specialization according to the raw material reduction phase, with some workshops located at or near the flint sources and others near the occupation sites. However, even if there were two types of workshops, the skills employed were the same, since an analysis of the flaking techniques showed that they were the same for all the raw materials. He infers that there were neither exchanges nor specialized flakers and that the objects that circulated were manufactured and transported by the same people, or at least the same groups. This result is interesting and well founded, but can we imagine that two individuals, or two different groups, had the same flaking skills? In any case, we have no basis for extending Bon's conclusions to the entire UP. And, once again, nothing can be said about the sex of these individuals.

Another possibility was explored by Maria-Anne Dobres (1995) based on a study of the bone tools from several Magdalenian sites. Dobres hypothesizes that the variability of technical "strategies" from one site to another could be due to a different organization of task distribution. For example, the percentage of repaired tools is highly variable, attaining $20 \%$ in some cases (e.g., at La Vache, where three-quarters of the tools repaired are harpoons). She hypothesizes that the composition of groups is not organized in the same manner at all the sites (e.g., sites with many repaired tools; sites where tools were made, etc.). At the sites where tools were manufactured, activities were planned for the long term, whereas at the sites where they were repaired, activities responded to an immediate need. According to Dobres, the less variability we observe in technical strategies, the more tool production activities were formalized. She interprets the variability observed among sites as evidence that specialization was low, since even if only some people had the skills and access to raw materials necessary to manufacture the objects (in stone and bone materials), everyone could repair them. She also suggests, however, that technical skills could vary according to age, sex, and social status.

\section{The Evidence of Grave Goods}

There are abundant ethnographic and historic examples of men buried with their weapons and tools and of women buried with their tools. It is thus logical to think that grave goods interred with the dead are informative regarding the specific activities of different individuals. Unfortunately, although we have some examples of this kind of evidence for the hunter-gatherer populations of the Mesolithic periods, it is more difficult to find for the UP. For the later periods of prehistory, in the first Mesolithic necropolises, skeletal remains are sufficiently abundant to enable statistical analyses. It is indeed easier to determine the sex of inhumed individuals in a larger population, since the features of sexual dimorphism, such as height and skeletal gracility, are easier 
to observe by comparing individuals within the same population. Skeletal data sometimes enable determinations of whether grave goods indeed differ between male or female tombs. In the Hoëdic necropolis, for example, personal ornaments buried with the dead appear to differ according to sex, but technical objects have greater utility for addressing the question of task distribution.

One of the most remarkable examples is provided by the Bogebakken necropolis at Vedbaek, a Danish coastal site excavated in 1975 that yielded 22 tombs dated to approximately $4,800 \mathrm{BC}$. All the bodies were deposited in an extended position and impregnated with red ocher. Grave goods were composed of animal teeth and red deer antler. Only men, however, were also accompanied by one or two flint blades attached to their waist. In one of the tombs (No. 8), a young woman around 18 years old, who perhaps died during childbirth, was accompanied by an infant, possibly stillborn. Both were adorned with numerous ornaments made of red deer and boar teeth, as well as perforated Neritina fluviatilis shells, and the child was laid out on a swan wing. But what is most intriguing is that the child was also accompanied by a flint blade, like the adult males in the necropolis (Albrethsen \& Petersen, 1976; Petersen, 1975). This suggests that this was a little boy and that the blades - perhaps dagger blades used for hunting or combat_constituted a male attribute rather than a tool used by the woman during her lifetime.

Mesolithic tombs would thus be the oldest to provide evidence for a gendered division of tasks, even if this practice may have existed well before then. Of course, more recent tombs dated to the Neolithic and Metal Ages also show significant differences in their grave goods, the most spectacular being the abundant warrior tombs of the Bronze Age. Even for these periods, however, we must remain cautious in our conclusions, since while some objects have a high symbolic value, they provide little information on their relationship to daily activities (Péré-Noguès, 2008).

What about older burials? The first difficulty is that there are very few such burials, and they are scattered through time and space. There are really not many UP burials: just over three per thousand years for the whole Eurasia (Riel-Salvatore \& Gravel-Miguel, 2013). It is thus difficult to detect recurrences, and we observe, on the contrary, a very high level of variability in funerary practices, whether in terms of the position of the body or the presence or absence of ornaments and grave goods. Two other difficulties add to this dispersion. The first concerns the association of grave goods with the deceased. Because many Paleolithic burials were found long ago, we often do not know if the flint or osseous tools found in the tomb were part of the funerary deposit or were accidentally introduced into the sediment filling the grave. There are nonetheless a few known cases of tools that were clearly associated with the deceased person. One of the oldest is the burial of an adolescent, dated to $23,440 \pm 190 \mathrm{BP}$ and attributed to the Gravettian, excavated in 1942 in the cave of Arene Candide in Liguria (Henry-Gambier, 2005). The young man, decorated with hundreds of perforated shells and laid on a bed of red ochre, held a $25-\mathrm{cm}$-long flint blade in his right hand, and four elk antler pierced batons had been placed by his sides. Similarly, the two children of the Sunghir burial, dated between 25,000 and 27,500 ${ }^{14} \mathrm{C}$ BP (Trinkaus et al., 2015), now believed to be a boy 11 to 13 years old and a girl perhaps 9 to 11 years old, ${ }^{3}$ were accompanied by numerous spear points and lances.

3 The sex assessment of these individuals is unreliable, and Trinkaus urges treating these data cautiously. 
These weapons were clearly associated with the bodies, apparently without consideration for their age or sex. Consequently, they do not enable us to determine the role of the buried individuals (Henry-Gambier, 2005; Trinkaus, Buzhilova, Mednikova, \& Dobrovolskaya, 2014).

The second difficulty with older burials is that given the poor state of preservation, the age of the deceased (pre-puberty), or the unreliability of the methods used, it is often difficult to determine the sex of the inhumed individual (Henry-Gambier, 2005). In previous decades, the sex of buried skeletons was attributed on the basis of robustness of the skull or the long bones, or the grave goods associated with them, which were usually interpreted in a sexist manner, resulting in an under-representation of females. More recent paleoanthropological studies have shown that these attributions were sometimes erroneous (Henry-Gambier, 2001). This is the case for the skeleton known as "the man of Menton," discovered in the cave of Cavillon (or La Barma de Caviglione, Italy) and dated to the Gravettian. The individual, deposited in a semiflexed position, was abundantly covered with ochre and wore an impressive headdress composed of 200 perforated shells that appear to have been attached to a hairnet. But it is based on the presence of numerous tools, including a bone dagger and two large flint blades, that this individual was identified as a male. However, one analysis of the coxal bone indicates that it is in fact an adult female (Brůžek, 1991; De Lumley, Stalens, \& Brůžek, 1992). This shows the "pressing need to re-examine existing collections of human remains in order to place the current study of gender, the body, and mortuary ritual on a more secure footing. Equally important in current research programs is the use of DNA, stable isotope analysis, and other types of scientific investigation in order to bring the study of the gendered body and the analysis of mortuary remains fully into the twenty-first century" (Bolger, 2013). Sébastien Villotte and his colleagues (Villotte, Brůžek, \& Henry-Gambier, 2011) have begun to perform such re-analysis on fossils from the European Gravettian.

We can conclude from these few examples that there are no clearly significant differences in grave goods associated with UP male and female tombs. We must thus be cautious in our interpretations of the nature of the grave goods accompanying the dead, as they can reveal things other than the distribution of tasks. We have to admit that grave goods are imperfect indicators of gender identity, that gender categories were not always the same, and that scholars can "play with" the rules. We have to keep in mind, and a few ethnographic examples could confirm it, that the variations in funerary practices within a single population can depend on a combination of information related to the association of the deceased with distinct categories (sex, age, class, origin), but also on the circumstances of their death.

\section{THE EVIDENCE OF OSTEOLOGICAL ANALYSIS}

Interpretations of gender in mortuary contexts must be based on skeletal material that has been sexed by osteological analysis, rather than through associated grave goods. The skeletal information provides data on health, nutrition, activity, physical stress or workload, risk, and mortality. Information in large quantity from skeletal analysis is relatively new. Mark Nathan Cohen and Sharon Bennett (1998) have presented a sample based on a review of the literature of applications of skeletal analysis to issues of gender inequality. But the major difficulty with much of archaeological data is that 
Paleolithic remains are isolated individuals. There is no evidence of large necropolises before the Mesolithic period. So there is some danger of facile over-interpretation of one individual skeletal to a whole population.

Concerning the division of tasks, one of the few ways to provide direct evidence on male and female tasks in the past has been the study of the dental remains and the osteological markers of activity. Dental wear patterns have been used to reconstruct activities in which the teeth are used as a tool or are used to act as a "third hand." Osteoarthritis, or other bone changes, results from regular adult activities such as climbing, kneeling, grinding grain, and carrying heavy loads. But once we consider the influence of age and genes, there is very little remaining evidence to suggest that activity is the main cause of arthritic bone changes. There are, however, a few exceptions, including Inuit skeletons with elbow arthritis related to extreme activities. Another type of alteration concerns the areas where muscles are attached to bones. Repeated uses of certain muscles produce changes to points of attachment. But once again, the causes of such bone changes are numerous and include age and genetic influences. These stress markers have been linked by some authors with subsistence change or sexual division of labor (Hawkey \& Merbs, 1995; Jurmain, 1999; Molleson, 1994; Molnar, 2006; Robb, 1998; Villotte, Churchill, Dutour, \& Henry-Gambier, 2010).

This kind of analysis is more common for the Neolithic and the Bronze and Iron Ages because of the presence of cemeteries with series of skeletal remains permitting statistical studies. For example, Alison Macintosh and colleagues (Macintosh, Pinhasi, \& Stock, 2014) presented an overview of analysis on bone adaptation among agriculturalist and metallurgist populations. She particularly studies variation of the upper limb asymmetry among males and females in Central Europe at the transition between the Neolithic and Early Bronze Age. Marked lateralization has also been documented, which may be the result of unilateral loading associated with the manufacture and use of many stone, bone, and metal tools and weapons. Similarly, Aline Thomas (2014) hypothesized an activity of archery in 36 male skeletons associated with arrowheads from European Middle Neolithic cemeteries. She observed a functional adaptation in the forearm bones and the clavicle in response to mechanical loads, as well as enthesopathies (or musculoskeletal stress, i.e., lesions of the tendon attachments) suggesting repeated forceful use of upper limb muscles, both findings supporting her hypothesis.

For the beginning of the Neolithic, the study of the cemeteries of Vedrovice (Moravia, Czech Republic) and Nitra Horné Krškany (western Slovakia) showed dental evidence of people having used their teeth as tools, possibly for the working of plant fibers and the production of cord or rope (Frayer, 2004; Jarašová \& Dočkalová, 2008). Another example concerns Molleson's (1994, 2007) observations of Abu Hureyra's Neolithic (Syria) female skeletons. She links the grooving of the chewing surfaces of front teeth to obtaining fibers for the production of baskets and sieves by some women. From the observation of metatarsals, phalanges, and other skeletal indications, she suggests that the daily chore of grinding grain fell predominantly to women, who kneeled with their toes curled under their feet.

Concerning hunter-gatherer populations, some studies are dedicated to Mesolithic necropolises. In Mesolithic southern Scandinavia, tooth wear in adult women reflects working hides by chewing, while wear on the teeth of men indicates holding materials. 
Although tooth wear increases with age for both sexes, it appears earlier among women (Alexandersen, 1993; Blankholm, 2008).

Brigitte M. Holt (2003) examined the evolution of mobility during the UP and Mesolithic through analysis of 81 UP and Mesolithic European femora and tibiae. The relationship between levels of mobility and lower-limb diaphyseal structure was used to test (and support) the hypothesized decrease in mobility during the Mesolithic. Among other results, she observed that sexual dimorphism levels in diaphyseal strength remain low throughout the three time periods (Early and Late UP and the Mesolithic), suggesting that there were no sex differences in behavior for UP and Mesolithic foragers. However, other analysis of human lower-limb bone structures from Neolithic and MP/UP samples indicates that sexual division of labor decreased over time, in particular in the relative mobility of males and females from huntinggathering to agricultural subsistence (Ruff, 1987).

In the case of subsistence strategies, unilateral enthesopathy of the medial epicondyle has been recognized previously as a good marker of spear/harpoons throwing by hand (Dutour, 1986). Sébastien Villotte and Christopher J. Knüsel (2014) analyzed enthesopathies of the elbow in prehistoric, pre-industrial, and modern European populations. The increased prevalence of pathological changes of the right medial epicondyle suggests lateralized limb use that corresponds with "thrower's elbow." This suggests that males, but not females, preferentially employed movements involving throwing motions in these hunter-gatherer and early farming groups. Based on this evidence, these authors postulate the existence of a persistent sexual division of labor in these prehistoric European populations, involving one or several strenuous activities linked to unilateral limb use.

In a previous analysis, Sébastien Villotte and colleagues (2010) assessed 16 males and 21 females from UP or Mesolithic European populations. Males exhibited lesions that can be confidently associated with throwing activities, while no females had such lesions. A sexual division of tasks concerning hunting seems most likely, based on the presence of injuries specific to spear throwing in male individuals and their absence among females. This division of labor would have begun during childhood or adolescence. Villotte and his team note in another publication that humeral asymmetry through the late Pleistocene is especially high among the males relative to the females, and consider the possibility of a division of labor between unimanual tasks (mostly male) and bimanual tasks (mostly female). At the same time, there is a general pattern of increased asymmetry with larger body size, but it remains unclear to what extent it reflects body size or sexual effects on bilateral humeral loading (Sparacello, Villotte, Shackelford, \& Trinkaus, 2016).

Marked levels of upper limb lateralization are not uncommon in UP samples, reflecting in most cases bone remodeling related to limb dominance and in other cases the effect of pathologically induced changes. The adult male of La Barma Grande also shows an unusually high degree of upper limb bilateral asymmetry, with the right side well above the mean values of other UP male specimens. However, comparisons involving normal and pathological Paleolithic remains, as well as recent skeletal samples, suggest that the phenomenon may be a secondary effect of pathological conditions such as muscular trauma (Churchill, 1994; Churchill \& Formicola, 1997).

Another study based on musculoskeletal stress markers of the upper limb on skeletal remains from the Natufian and the early farming populations in the Levant 
indicates a gender-based division of labor in both the Natufian and Neolithic (Eshed, Gopher, Galili, \& Hershkovitz, 2004). Sládek and colleagues (2016) compared upper limb bone bilateral asymmetry in a large $(n>1200)$ European sample distributed among 11 archaeological periods from the early UP through the twentieth century. They intended to show that the trajectory from UP to Neolithic was different for males and females. For instance, changes in manipulative behavior were sex-specific with a probable higher impact of changes in hunting behavior on male asymmetry (e.g., shift from unimanual throwing to use of the bow and arrow) and food grain processing in females - specifically, use of two-handed saddle querns in the early agricultural periods and one-handed rotary querns in later agricultural periods (Sládek et al., 2016).

Although this chapter is specially focused on the UP, it is nonetheless interesting to note that an analysis of activity-related dental wear patterns in 19 Neandertal fossils from three different sites reveals that all individuals have cultural striations, but those detected on the adult females are longer than the striations found in adult males. Regarding the distribution of dental chipping, in males this trait is more prevalent in the maxillary dentition, whereas in females most of the dental chipping is on their mandibular teeth. The differences detected in the overall activity-related dental wear pattern denote a difference or a division of labor by age and sex in Neandertals when the mouth is used as a third hand (i.e., in activities other than the provisioning of food). These findings provide new evidence for the lifestyle of this Pleistocene fossil human species, indicating subtle differences that suggest individual roles within the groups (Estalrrich \& Rosas, 2015). This analysis contradicts that by Kuhn and Stiner presented earlier.

The literature regarding the markers of activities on bones and dental remains is too large to review here. However, Robert Jurmain and colleagues (Jurmain, Cardoso, Henderson, \& Villotte, 2012) have comprehensively reviewed the topic and show the limits of these analyses. The fact that some examples are self-contradictory may indicate that mobility and subsistence gender tasks varied in time and space in different hunter and gatherer populations. In any case, such analyses are surely one of the best ways to reconstruct activities of the past populations and obtain direct evidence of the sexual division of tasks, provided one avoids overgeneralization.

\section{Male and Female Handprints}

Research in Paleolithic rock art has suggested gendered explanations, but most of them are interpretations influenced by a specific ideology (Hays-Gilpin, 2004, 2013). Few of these studies have tried to support their assertions with archaeological evidence. One of these hypotheses, presented next, is interesting because the author proposes to prove that the artists were women-which is not so common-and deduces his theory from archaeological evidence and not just from firm conviction.

According to Dean Snow (2013), the artists who decorated caves were women. He bases this interpretation on a study of negative hand stencils (i.e., stencils made by blowing paint against hands placed on the cave wall, which outline the hand while the hand itself leaves an unpainted or negative space) in a few decorated caves. To establish the sex of the authors of the hand stencils, he used an index developed by John Manning (2002) based on the length of the index and annular fingers. According to 
this index, these fingers are the same length for women, whereas for men the index finger is shorter than the annular finger. Snow was not the first to use this index; it was previously tested on the negative handprints in the cave of Masri II east of Borneo (Indonesia). Snow tested this index on 32 hands from eight different caves (including 16 from El Castillo, 6 from Gargas, and 5 from Pech Merle) and deduced that 24 of them were female. Based on a comparison with the hands of male and female American students, he also concluded that sexual dimorphism was greater during the UP than it is now. A few years earlier, R. Dale Guthrie (2005) performed a similar study based on the width of the palm and the thumb and concluded that the majority of painted hands belonged to adolescents.

The samples used in these studies are small because most of the handprints were incomplete (i.e., intentionally represented using only two or three fingers). We can thus question the statistical validity of such a study, and even more so because negative handprints are found only within a short time range, corresponding to the Gravettian period. Nonetheless, in the few caves concerned, Guthrie and Snow agree that adult male hands correspond to only around $10 \%$ of the total number of hands represented. Men were therefore not the only ones to participate in artistic activities.

\section{CONCLUDING PROPOSITIONS}

Based on the information presented here, I propose that there was a reasoned distribution of activities within groups, accompanied by an emerging social hierarchy, but that it is very difficult to make conclusions about the gendering of activities because the sex of artisans is unknown.

\section{A Distribution of "Workshop" Activities}

It appears that a form of task distribution existed, for at least two reasons. First, life within a society implies a capacity to manage the equilibrium of all the means employed to ensure the survival of the group. François Sigaut often discussed this idea ${ }^{4}$ with reference to the "workshop" concept arising from the school of Frédéric Le Play and applied to "wild peoples" by Paul Descamps (1923). Here, the notion of a workshop designated the manner in which a given activity was distributed among a social group in the form of simultaneous or successive, but connected, tasks. This implies that a prehistorian (and an anthropologist of techniques) is not interested in a particular activity, but rather in the entire repertoire of activities of a social group and in the different tasks composing these activities, in order to understand the balance of the whole ensemble. 5 Thanks to this notion, the problem of task distribution between the sexes can be seen in a new light-that is, there are no specifically male or female tasks. To understand the nature of this distribution, we consider all of the tasks practiced by all of the members of a social group and their organization within workshops. Along these lines, based on the data gathered from 71 hunter-gatherer populations,

4 Particularly in the context of seminars at the École des Hautes Études en Sciences Sociales, Paris (see de Beaune, 2013).

5 This notion of "workshop" explains how small changes can have unexpectedly significant repercussions. 
Nicole M. Waguespack (2005) showed that the amount of time spent by women to collect vegetal resources varied depending on the degree of dependence on the meat of large herbivores hunted by men. The most time-consuming task was obtaining and sharing meat for daily consumption, which influenced the time spent collecting wild plants. The more they abandoned the collection of wild plants, the more time would be devoted to other technical and non-food-related activities. Another example comes from the Inuit: If an Inuit family has no son, the father may train one or two daughters to hunt. Similarly, families with few daughters may teach sons sewing and other female skills, and orphans learn both men's and women's skills (Briggs, 1970; Endicott, 2004). Hetty Jo Brumbach and Robert Jarvenpa observed that different activities among the Chipewyan require greater or lesser degrees of logistical organization, and this balance can change over time as external factors change. For instance, as part of the population became more sedentary, another part (men) needed to "become increasingly mobile and logistically organized” (Brumbach \& Jarvenpa, 1997). Also, as prey size increases, the tasks of butchering, processing, storing, and distributing food tend to fall on women rather than men, at least in these particular circumpolar societies (Jarvenpa \& Brumbach, 2009). This suffices to show that the dichotomous view of women collecting vegetal resources and men hunting is simplistic and does not take into account the balance between all of the tasks carried out by the members of a community.

The second reason is that regardless of the task or activity considered, we can reasonably suppose that it was preferentially assigned to the individual, male or female, who was best equipped to succeed at it. However, while some activities can be performed by any member of the group, others-particularly in the technical and artistic domains - require a certain degree of competence. Knowing that individual aptitudes vary from one individual to another, we can infer that there are specialists in bone, flint, hide, and other material working to whom the manufacturing and maintenance of artifacts was entrusted. Without going so far as to suggest craft specialization, we can imagine that even if the entire group had the same global knowledge, some adults focused on performing the tasks for which they were best suited. To take a contemporary example, all Tuareg blacksmiths know more or less how to make a great variety of artifacts, but they often choose to specialize in making whatever kind of article they feel most skilled at doing; some make camel saddles, others wood spoons, or spades, or jewels (Casajus, 1987). Also relevant here is the case of a 35- to 40-yearold man of the Fish Creek group from Australia: He was a skillful craftsman, able to repair spear points and spear throwers and produce pipes and bullroarers, who was exempted from all food tasks (McCarthy \& McArthur, 1960). As another example, Deborah Olausson (2008) explored the flint technology in southern Scandinavia during the Late Neolithic, especially craft expertise and its potential as a factor in aggrandizer strategies. She argues that there are elements of natural aptitude that enabled certain individuals to excel at flintknapping, allowing them to create objects of exceptional size and beauty. If native ability in a particular domain is a rare commodity, then harnessing it and developing it through practice provides an opportunity for a potential aggrandizer to control prestige goods and accrue social capital. We should not exclude the likelihood that the same would have occurred in the European UP.

We have seen that there is clear evidence for different competence levels in knapping stone during the UP, implying that adults transmitted their knowledge 
and skills to younger individuals through apprenticeship modalities (see, for instance, Tostevin, 2012, on the transmission of flintknapping behaviors). The skill level necessary to manufacture handaxes indicates that this specialization already existed tens or even hundreds of thousands of years previously, in the MP. These groups required social structures with which to facilitate the learning process. Peter Hiscock (2014) argues that the development of apprentice-master relationships would have enhanced differentiated labor roles and the growth of specialization within small groups.

This must have been true in the artistic domain as well, since the art in Lascaux and elsewhere could not have been done by just anybody. The techniques used throughout the UP-engravings, sculpture and painting — do not appear to have significantly evolved during the 30,000 years of portable and parietal art; on the contrary, they appear to have been fully developed from the beginning of the UP (de Beaune, 2018). These artists had not only specific capabilities but also the privilege to enter into the depths of the cavern and to leave their mark, characteristics that would have distinguished them from their peers. Independent of a particular status (shaman, sorcerer, priest, etc.) granted to the artist by at least some members of the group, he or she was an individual whose skills were recognized. This suggests that the artist would have played a specific role in the group, perhaps comparable to that of the carvers of totem poles in a Northwest Coast native community, whose talents justified their maintenance by the rest of the group (Leroi-Gourhan, 1982). Of note, these carvers were never full-time artists; they were also engaged in food-collecting activities such as fishing. Apprentices were trained by artists from their communities (artists were usually high-status individuals; Marie Mauzé, personal communication). Like skilled stone workers, the artists were probably accompanied by young apprentices, since one would never venture alone into a cavern, for basic security reasons, and because help from an assistant to hold the lamp or prepare the colorants was indispensable.

Furthermore, simple logic suggests that, even if women were restricted to domestic tasks, they must also have been able to carry out the technical tasks traditionally assigned to men. For instance, if they were able to cook, they must have been able to make a fire. If they cut carcasses into pieces and worked hides, they used stone and bone tools; as these tools wear out quickly, they must have been able to make or at least resharpen them and thus to work stone and bone. All of these techniques are usually considered to be reserved for men.

\section{Possible Evidence for an Emerging Social Hierarchy}

If we accept that there was a dense population during the UP, that groups periodically gathered into large residential units, or that they were relatively sedentary (Conkey, 1980, 1985; Hayden, 1981; Mellars, 1985), then we can suppose that individuals with a particular status emerged. They would have been responsible for things such as organizing and coordinating the activities of the group, ensuring the distribution of food and other resources, and perhaps serving as mediators in conflicts.

The existence of such persons is difficult to prove on the basis of archaeological evidence. The fact that only some individuals were buried during the UP indicates potential social differentiation. However, distinct treatments of the inhumed bodies make it difficult to determine whether any specific treatment existed for men or for 
women, or the old versus the young. UP burials differ widely in terms of their elaboration, even within single regions, and sometimes even within a single site. There is no such thing as a "typical" UP burial. Gender ratios changed over time and are difficult to interpret (Riel-Salvatore \& Gravel-Miguel, 2013), and there appear to be no significant differences between male and female ornaments (Marian Vanhaeren, personal communication). Brigitte M. Holt and Vincenzo Formicola (2008) have noted that for the Late UP there was an intriguing and unexpected incidence of individuals affected by congenital disorders, which probably indicates selective burial practices for abnormal individuals. We therefore cannot eliminate the hypothesis that inhumation was reserved for certain members of the group, and perhaps their families, related to a particular social status.

Brian Hayden $(2001,2013)$ has proposed a revision of the traditional model of these societies as largely egalitarian, like the hunter-gatherer societies observed in Africa (Childe, 1954). In his study, the groups occupying the most favorable environments, such as in southwestern France, would have belonged to the same category of relatively complex and hierarchical hunter-gatherer societies as those of the Pacific Northwest Coast of North America. These societies had significant socioeconomic inequalities, were more sedentary, and had higher demographic densities. Moreover, they openly fought among themselves in rivalries based on wealth, possessed prestige objects, obtained certain resources and wealth in an exclusive manner, and shared very little. Some archaeological evidence at Magdalenian sites in southwestern France suggests similarities with these societies, which could be due to an underlying surplus production resulting from the massive exploitation of migratory and other species: salmon on the Pacific Northwest Coast plateau, reindeer and other herd animals in France. Based on an analysis of the geographic distribution of sites and their surface area, as well as of some remains such as burials and personal ornaments, Hayden even suggests that there was a specialization of sites and thus of tasks, and that different social statuses among individuals already existed in Neandertal societies. To him it is evident that the sexual distribution of tasks was highly developed, as it is in all known hunter-gatherer societies (Hayden, 2012).

Technological studies of the grave goods associated with burials and their comparison with ornaments and faunal assemblages from contemporary sites and burials reveal the exceptional character of some of the inhumations, like those of Saint-Germain-La Rivière, La Madeleine, La Grotte des Enfants, and Sunghir (e.g., Vanhaeren, 2002; Vanhaeren \& d'Errico, 2001, 2003; White, 1999). As observed in a number of hunter-gatherer populations, and contrary to the supposed egalitarian character of UP societies, these items may indicate that an individual was a member of a privileged social group (Vanhaeren \& d'Errico, 2003).

In conclusion, regarding the division of labor along gender lines in the Paleolithic, there is evidence for emerging activity specialization, but it is difficult or impossible to reliably assign it to specific genders. I will end this chapter by insisting again that we must be cautious in our interpretations, as what we seek to understand is the identity of our Paleolithic ancestors, identity that forcibly evolved throughout millennia of prehistory and was subject to the ebbs and flows that shaped the history of Paleolithic societies (de Beaune, 2016; Lenclud, 2003). 


\section{ACKNOWLEDGMENTS}

I thank two anonymous reviewers for their very valuable comments, which helped me improve this chapter.

\section{REFERENCES}

Adovasio, J. M., Soffer, O., \& Page, J. (2007). The invisible sex: Uncovering the true roles of women in prehistory. Walnut Creek, CA: Left Coast Press.

Albrethsen, S. E., \& Petersen, E. B. (1976). Excavation of a Mesolithic cemetery at Vedbæk, Denmark. Acta Archeologica, 47, 1-28.

Alexandersen, V. (1993). Teeth: Health, disease and use. In S. Hvass \& B. Storgaard (Eds.), Digging into the past: 25 years of archaeology in Denmark (p. 81). Copenhagen: Aarhus Universitetsforlag.

Arthur, K. W. (2010). Feminine knowledge and skill reconsidered: Women and flaked stone tools. American Anthropologist, 112(2), 228-243.

Astruc, L. (2005). Approches multi-échelles de la spécialisation technique: Les industries lithiques taillées du Néolithique pré-céramique au Proche-Orient. Techniques \& Culture, 46/ 47, 79-104.

Audouze, F. (2010). Domesticity and spatial organization at Verberie. In E. B. W. Zubrow, F. Audouze, \& J. G. Enloe (Eds.), The Magdalenian household: Unraveling domesticity (pp. 145175). Albany, NY: State University of New York Press.

Audouze, F., \& Beyries, S. (2007). Chasseurs de rennes d'hier et d'aujourd'hui. In S. Beyries \& V. Vaté (Eds.), Les Civilisations du Renne d'hier et d'aujourd'hu: Approches ethnohistoriques, archéologiques et anthropologiques (pp. 185-208). Antibes: Éditions APDCA.

Baffier, D., Julien, M., \& Karlin, C. (1981). La femme et la préhistoire. Pénélope, 4, 95-99.

Balikci, A. (1970). The Netsilik Eskimo. Prospect Heights, IL: Waveland Press.

Bamforth, D. B., \& Finlay, N. (2008). Introduction: Archaeological approaches to lithic production skill and craft learning. Journal of Archaeological Method and Theory, 15(1), 1-27.

Baron-Cohen, S., Knickmeyer, R. C., \& Belmonte, M. K. (2005). Sex differences in the brain: Implications for explaining autism. Science, 310(5749), 819-823.

Bégouën, H. (1924). La magie aux temps préhistoriques. Mémoires de l'Académie des sciences, 12(II), 417-432.

Bégouën, H. (1939). Les bases magiques de l’art préhistorique. Scientia, 4(33), 202-216.

Bird, C. F. M. (1993). Woman the tool maker: Evidence for women's use and manufacture of flaked stone-tools in Australia and New Guinea. In H. du Cros \& L. Smith (Eds.), Women in archaeology: A feminist critique (pp. 22-30). Canberra: Australian National University.

Blankholm, H. P. (2008). Southern Scandinavia. In G. Bailey \& P. Spikins (Eds.), Mesolithic Europe (pp. 107-131). Cambridge, UK: Cambridge University Press.

Bolger, D. (2013). Introduction: Gender prehistory-The story so far. In D. Bolger (Ed.), A companion to gender prehistory (pp. 1-19). Chichester, UK: Wiley-Blackwell.

Bon, F. (2005). Être un ou plusieur: Quelles différences pour l'Aurignacien? Techniques \& Culture, 46/47, 35-49.

Bosinski, G. (2007). Gönnersdorf und Andernach-Martinsberg: Späteiszeitliche Siedlungsplätze am Mittelrhein. Koblenz, Germany: Gesellschaft für Archäologie am Mittelrhein und Mosel e.V. 
Bosinski, G., \& Fischer, G. (1974). Die Menschendarstellungen von Gönnersdorf: Der Ausgrabung 1968. Der Magdalénien —Fundplatz Gönnersdorf 1. Wiesbaden, Germany: Steiner.

Breuil, H. (1952). Quatre cents siècles d'art pariétal: Les cavernes ornées de l'Âge du Renne. Montignac: Centre d'Études et de Documentation préhistoriques.

Briggs, J. L. (1970). Never in anger: Portrait of an Eskimo family. Cambridge, MA: Harvard University Press.

Brown, D. E. (1991). Human universals. New York: McGraw-Hill.

Brumbach, H. J., \& Jarvenpa, R. (1997). Ethnoarchaeology of subsistence space and gender: A subarctic Dene case. American Antiquity, 62(3), 414-436.

Brůžek, J. (1991). Fiabilité des procédés de détermination du sexe à partir de l'os coxal: Implications à l'etude du dimorphisme sexuel de l'homme fossile. Doctoral thesis, Institut de paleontologie humaine, Museum national d'Histoire naturelle, Paris.

Casajus, D. (1987). Craft and ceremonies: The Inadan in Tuareg society. In A. Rao (Ed.), The other nomads: Peripatetic minorities in cross-cultural perspective (pp. 291-310). KölnWien: Böhlau Verlag.

Casey, J. (1998). Just a formality: The presence of fancy projectile points in a basic tool assemblage. In S. Kent (Ed.), Gender in African prehistory (pp. 83-103). London: SAGE.

Childe, V. G. (1954). Early forms of societies. In C. Singer, E. J. Holmyard, A. R. Hall, \& T. I. Williams (Eds.), A history of technology (Vol. 1, pp. 38-57). Oxford, UK: Clarendon Press.

Churchill, S. E. (1994). Human upper body evolution in the Eurasian Later Pleistocene. Doctoral thesis, University of New Mexico.

Churchill, S. E., \& Formicola, V. (1997). A case of marked bilateral asymmetry in the upper limbs of an Upper Paleolithic male from Barma Grande (Liguria), Italy. International Journal of Osteoarchaeology, 7(1), 18-38.

Clottes, J. (2015). Pourquoi l’art préhistorique? Paris: Gallimard.

Codding, B. F., Bird, R. B., \& Bird, D. W. (2011). Provisioning offspring and others: Riskenergy trade-offs and gender differences in hunter-gatherer foraging strategies. Proceedings of the Royal Society of London B: Biological Sciences, 278(1717), 2502-2509.

Cohen, M. N., \& Bennett, S. (1998). Skeletal evidence for sex roles and gender hierarchies in prehistory. In B. D. Miller (Ed.), Sex roles and gender hierarchies (pp. 273-296). Cambridge, UK: Cambridge University Press.

Conkey, M. W. (1980). The identification of prehistoric hunter-gatherer aggregation sites: The case of Altamira. Current Anthropology, 21(5), 609-630.

Conkey, M. W. (1985). Ritual communication, social elaboration, and the variable trajectories of Paleolithic material culture. In T. D. Price \& J. A. Brown (Eds.), Prehistoric huntergatherers: The emergence of cultural complexity (pp. 299-323). New York: Academic Press.

Costin, C. L. (2013). Gender and textile production in prehistory. In D. Bolger (Ed.), A companion to gender prehistory (pp. 180-202). Chichester, UK: Wiley-Blackwell.

Dahlberg, F. (Ed.). (1981). Woman the gatherer. New Haven, CT: Yale University Press.

de Beaune, S. A. (2000). Pour une archéologie du geste: Broyer, moudre, piler, des premiers chasseurs aux premiers agriculteurs. Paris: Éditions CNRS.

de Beaune, S. A. (2013). François Sigaut (1940-2012), agronome et technologue. Revue de synthèse, 134(1), 115-124.

de Beaune, S. A. (2016). Qu'est-ce que la préhistoire? Paris: Gallimard.

de Beaune, S. A. (2018). Vertical transfer of knowledge on the Longue durée: Technical perspective on the development of Upper Paleolithic art in Europe. In S. Hansen, F. Klimscha, \& 
J. Renn (Eds.), Proceedings of the international conference: "Prehistoric networks in the Longue durée: Palaeolithic innovations enabling the Neolithic revolution." Berlin: Topoi.

Debout, G. (2007). Un atelier de peausserie il y a 12000 ans à Pincevent? In S. Beyries \& V. Vaté (Eds.), Les Civilisations du Renne d'hier et d'aujourd'hu: Approches ethnohistoriques, archéologiques et anthropologiques (pp. 439-455). Antibes: Éditions APDCA.

Delporte, H. (1990). L'image des animaux dans l'art préhistorique. Paris: Picard.

De Lumley, H., Stalens, H., \& Brůžek, J. (1992). Nouvelles données sur la sépulture de l’homme de Menton, Grotte du Cavillon (Baoussé-Roussé, Grimaldi, Italie). Communication à la réunion de la Société préhistorique française, séance de janvier 1992.

Descamps, P. (1923). L'atelier chez les sauvages. Revue de l'Institut de sociologie, I(3), 352-378.

Dobres, M. (1995). Gender and prehistoric technology: On the social agency of technical strategies. World Archaeology, 27(1), 25-49.

Donohoe, F. (2009). "Hand him over to me and I shall know very well what to do with him": The gender map and ritual native female violence in early America. In K. Williams, R. Jones, H. Van Koten, \& C. Murray (Eds.), Debating the difference: Gender, representation and selfrepresentation. Dundee, Scotland: University of Dundee.

Dutour, O. J. (1986). Enthesopathies (lesions of muscular insertions) as indicators of the activities of Neolithic Saharan populations. American Journal of Physical Anthropology, 71(2), 221-224.

Eals, M., \& Silverman, I. (1994). The hunter-gatherer theory of spatial sex differences: Proximate factors mediating the female advantage in recall of object arrays. Ethology and Sociobiology, $15(2), 95-105$.

Endicott, K. L. (2004). Gender relations in hunter-gatherer societies. In R. B. Lee \& R. H. Daly (Eds.), The Cambridge encyclopedia of hunters and gatherers (Reprint ed., pp. 411-418). Cambridge, UK: Cambridge University Press.

Eren, M. I., Bradley, B. A., \& Sampson, C. G. (2011). Middle Paleolithic skill level and the individual knapper: An experiment. American Antiquity, 76(2), 229-251.

Eshed, V., Gopher, A., Galili, E., \& Hershkovitz, I. (2004). Musculoskeletal stress markers in Natufian hunter-gatherers and Neolithic farmers in the Levant: The upper limb. American Journal of Physical Anthropology, 123(4), 303-315.

Estalrrich, A., \& Rosas, A. (2015). Division of labor by sex and age in Neandertals: An approach through the study of activity-related dental wear. Journal of Human Evolution, 80, 51-63.

Estioko-Griffin, A., \& Griffin, P. B. (1981). Woman the hunter: The Agta. In F. Dahlberg (Ed.), Woman the gatherer (pp. 121-151). New Haven, CT: Yale University Press.

Finlay, N. (2013). Gender and lithic studies in prehistoric archaeology. In D. Bolger (Ed.), A companion to gender prehistory (pp. 142-160). Chichester, UK: Wiley-Blackwell.

Frayer, D. W. (2004). The dental remains from Krškany (Slovakia) and Vedrovice (Czech Republic). Anthropologie, 42(1), 71-103.

Gerasimov, M. M. (1958). Paleoliticheskaya stoyanka Mal'ta (Raskopki 1956-1957 gg.). Sovetskaya Etnografiya, 3, 28-52.

Gifford-Gonzalez, D. (1993). You can hide, but you can't run: Representation of women's work in illustrations of Palaeolithic life. Visual Anthropology Review, 9(1), 3-21.

Gomart, L., \& Burnez-Lanotte, L. (2012). Techniques de façonnage, production céramique et identité de potiers: Une approche technologique de la céramique de style non rubané du site du Staberg à Rosmeer (Limbourg, Belgique). Bulletin de la Société préhistorique française, 2012, 231-250. 
400 Squeezing Minds From Stones

Goodale, J. C. (1971). Tiwi wives: A study of the women of Melville Island, North Australia. Seattle, WA: University of Washington Press.

Guthrie, R. D. (1984). Ethological observations from Paleolithic art. In H.-G. Bandi, W. Huber, M.-R. Sauter, \& B. Sitter (Eds.), La contribution de la zoologie et de l'éthologie à l'interprétation de l'art des peuples chasseurs préhistoriques (pp. 35-74). Fribourg, Switzerland: Éditions Universitaires.

Guthrie, R. D. (2005). The nature of Paleolithic art. Chicago, IL: University of Chicago Press.

Hardy, B. L., \& Moncel, M.-H. (2011). Neanderthal use of fish, mammals, birds, starchy plants and wood 125-250,000 years ago. PLoS One, 6(8), 1-10.

Hawkey, D. E., \& Merbs, C. F. (1995). Activity induced musculoskeletal stress markers (MSK) and subsistence strategy changes among ancient Hudson Bay Eskimos. International Journal of Osteoarchaeology, 5(4), 324-338.

Hayden, B. (1981). Research and development in the Stone Age. Current Anthropology, 22(5), 519-548.

Hayden, B. (1992). Observing prehistoric women. In C. Claasen (Ed.), Exploring gender through archaeology: Selected papers from the 1991 Boone conference (pp. 33-47). Madison, WI: Prehistoric Press.

Hayden, B. (2001). Richman, poorman, beggarman, chief: The dynamics for social inequality. In G. M. Feinman \& T. D. Price (Eds.), Archaeology at the millennium: A sourcebook (pp. 231271). New York: Kluwer/Plenum.

Hayden, B. (2012). Neandertal social structure? Oxford Journal of Archaeology, 31(1), 1-26.

Hayden, B. (2013). Naissance de l'inégalité. L'invention de la hiérarchie durant la préhistoire. Paris: Éditions CNRS.

Hays-Gilpin, K. A. (2004). Ambiguous images: Gender and rock art. Walnut Creek, CA: Altamira Press.

Hays-Gilpin, K. A. (2013). Gender and prehistoric rock art. In D. Bolger (Ed.), A companion to gender prehistory (pp. 122-141). Chichester, UK: Wiley-Blackwell.

Henry, A. G., Brooks, A. S., \& Piperno, D. R. (2010). Microfossils in calculus demonstrate consumption of plants and cooked foods in Neanderthal diets (Shanidar III, Iraq; Spy I and II, Belgium). Proceedings of the National Academy of Sciences of the United States of America, 108(2), 486-491.

Henry-Gambier, D. (2001). La sépulture des enfants de Grimaldi (Baoussé-Roussé, Italie): Anthropologie et palethnologie funéraire des populations de la fin du Paléolithique supérieur. Paris: Comité des Travaux historiques et scientifiques.

Henry-Gambier, D. (2005). Évolution des pratiques funéraires en Italie au Paléolithique supérieur. In D. Vialou, J. Renault-Miskovsky, \& M. Patou (Eds.), Comportements des hommes du Paléolithique moyen et supérieur en Europe: Territoires et milieux (pp. 213-229). Liège: ERAUL 111.

Hiscock, P. (2014). Learning in lithic landscapes: A reconsideration of the hominid "toolmaking" niche. Biological Theory, 9(1), 27-41.

Holt, B. M. (2003). Mobility in Upper Paleolithic and Mesolithic Europe: Evidence from the lower limb. American Journal of Physical Anthropology, 122(3), 200-215.

Holt, B. M., \& Formicola, V. (2008). Hunters of the Ice Age: The biology of Upper Paleolithic people. American Journal of Physical Anthropology, 137(S47), 70-99.

Iakovleva, L., \& Pinçon, G. (1997). La frise sculptée du Roc-aux-Sorciers: Angles-sur-l'Anglin (Vienne). Paris: Comité des Travaux historiques et scientifiques. 
Ingold, T. (2004). On the social relations of the hunter-gatherer band. In R. B. Lee \& R. H. Daly (Eds.), The Cambridge encyclopedia of hunters and gatherers (Reprint ed., pp. 399-410). Cambridge, UK: Cambridge University Press.

Janny, F. (2010). Technologie lithique à Verberie: Production domestique et apprentissage. In E. B. W. Zubrow, F. Audouze, \& J. G. Enloe (Eds.), The Magdalenian household: Unraveling domesticity (pp. 51-75). Albany, NY: State University of New York Press.

Jarašová, I., \& Dočkalová, M. (2008). Dental remains from the Neolithic settlements in Moravia, Czech Republic. Anthropology, 46(1), 77-101.

Jarvenpa, R., \& Brumbach, H. J. (2009). Fun with Dick and Jane: Ethnoarchaeology, circumpolar toolkits, and gender "inequality." Ethnoarchaeology, 1(1), 57-78.

Johansen, L., \& Stapert, D. (2008). Stone age kids and their stones. In M. Sørensen \& P. Desrosiers (Eds.), Technology in archaeology: Proceedings of the SILA Workshop: The study of technology as a method for gaining insight into aocial and cultural aspects of prehistory (pp. 1539). Copenhagen: National Museum of Denmark.

Jurmain, R. (1999). Stories from the skeleton: Behavioral reconstruction in human osteology. London: Taylor and Francis.

Jurmain, R., Cardoso, F. A., Henderson, C., \& Villotte, S. (2012). Bioarchaeology's Holy Grail: The reconstruction of activity. In A. L. Grauer (Ed.), A companion to paleopathology (pp. 531-542). New York: Wiley-Blackwell.

Kaplan, H., Hill, K., Lancaster, J., \& Hurtado, A. M. (2000). A theory of human life history evolution: Diet, intelligence, and longevity. Evolutionary Anthropology: Issues, News, and Reviews, 9(4), 156-185.

Kelly, R. L. (1995). The foraging spectrum: Diversity in hunter-gatherer lifeways. Washington, DC: Smithsonian Institution Press.

Kent, K. P. (1971). Introducing West African cloth. Denver, CO: Denver Museum of Natural History.

Kent, S. (Ed.). (1996). Cultural diversity among twentieth-century Foragers: An African perspective. Cambridge, UK: Cambridge University Press.

Knüsel, C. J., \& Smith, M. J. (2013). The osteology of conflict: What does it all mean? In C. J. Knüsel \& M. J. Smith (Eds.), The Routledge handbook of the bioarchaeology of human conflict (pp. 656-694). London: Routledge.

Kriger, C. E. (2006). Cloth in West African history. Lanham, MD: Altamira Press.

Kuhn, S. L., \& Stiner, M. C. (2006). What's a mother to do? The division of labor among Neandertals and modern humans in Eurasia. Current Anthropology, 47(6), 953-981.

Le Dosseur, G. (2005). La spécialisation des tâches au début de la néolithisation au Levant: L'exploitation des matières osseuses au Natoufien. Techniques \& Culture, 46/47, $105-138$

Lee, R. B. (1979). The !Kung San: Men, women and work in a foraging society. Cambridge, UK: Cambridge University Press.

Lee, R. B. (1982). Politics, sexual and non-sexual, in an egalitarian society. In E. Leacock \& R. B. Lee (Eds.), Politics and history in band societies (pp. 37-59). Cambridge, UK: Cambridge University Press.

Lee, R. B. (1988). Reflections on primitive communism. In T. Ingold, D. Riches, \& J. Woodburn (Eds.), Hunters and gatherers, Volume 1: History, evolution and social change (pp. 252-268). Oxford, UK: Berg. 
402 Squeezing Minds From Stones

Lee, R. B., \& Daly, R. H. (2004). Introduction: Foragers and others. In R. B. Lee \& R. H. Daly (Eds.), The Cambridge encyclopedia of hunters and gatherers (Reprint ed., pp. 1-19). Cambridge, UK: Cambridge University Press.

Lee, R. B., \& DeVore, I. (Eds.). (1968a). Man the hunter: The first intensive survey of a single, crucial stage of human development-Man's once universal hunting way of life. Chicago, IL: Aldine Transaction.

Lee, R. B., \& DeVore, I. (1968b). Problems in the study of hunters and gatherers. In R. B. Lee \& I. DeVore (Eds.), Man the hunter: The first intensive survey of a single, crucial stage of human development-Man's once universal hunting way of life (pp. 3-12). Chicago, IL: Aldine Transaction.

Lenclud, G. (2003). Identité et changement sont-ils compatibles? In M. Bley (Ed.), Grand dictionnaire de la philosophie (pp. 512-516). Paris: Éditions Larousse-CNRS.

Lenclud, G. (2013). L'universalisme ou le pari de la raison: Anthropologie, histoire, psychologie. Paris: Gallimard.

Leroi-Gourhan, A. (1982). Les racines du monde: Entretiens avec Claude-Henri Rocquet. Paris: Pierre Belfond.

Luders, E., Gaser, C., Narr, K. L., \& Toga, A. W. (2009). Why sex matters: Brain size independent differences in gray matter distributions between men and women. Journal of Neuroscience, 29(45), 14265-14270.

Macintosh, A. A., Pinhasi, R., \& Stock, J. T. (2014). Divergence in male and female manipulative behaviors with the intensification of metallurgy in Central Europe. PLoS One, 9(11), 1-17.

Manning, J. T. (2002). Digit ratio: A pointer to fertility, behavior, and health. New Brunswick, NJ: Rutgers University Press.

Marlowe, F. W. (2007). Hunting and gathering: The human sexual division of foraging labor. Cross-Cultural Research, 41(2), 170-195.

McCarthy, F. D., \& McArthur, M. (1960). Food consumption and dietary levels of groups of Aborigines living on naturally occurring foods. In C. P. Mountford (Ed.), Records of the Australian-American scientific expedition to Arnhem Land, 1948. Vol. II. Anthropology and nutrition (pp. 90-135). Melbourne: Melbourne University Press.

McDonald, J. (1992). The Great Mackerel rockshelter excavation: Women in the archaeological record? Australian Archaeology, 35(1), 32-50.

Mellars, P. (1985). The ecological basis of social complexity in the Upper Paleolithic of Southern France. In T. D. Price \& J. A. Brown (Eds.), Prehistoric hunter-gatherers: The emergence of cultural complexity (pp. 271-297). New York: Academic Press.

Molleson, T. I. (1994). The eloquent bones of Abu Hureyra. Scientific American, 271(2), 70-75.

Molleson, T. I. (2007). Bones of work at the origins of labour. In S. Hamilton, R. D. Whitehouse, \& K. I. Wright (Eds.), Archaeology and women: Ancient and modern issue (pp. 185-198). Walnut Creek, CA: Left Coast Press.

Molnar, P. (2006). Tracing prehistoric activities: Musculoskeletal stress marker analysis of a stone-age population on the Island of Gotland in the Baltic Sea. American Journal of Physical Anthropology, 129(1), 12-23.

Morgan, L. J. (1877). Ancient Society, or Researches in the Lines of Human Progress, from Savagery through Barbarism to Civilization. LL. D. New York: Henry Holt \& Co.

Murdock, G. P. (1967). Ethnographic atlas: A summary. Ethnology, 6(2), 109-236.

Murdock, G. P., \& Provost, C. (1973). Factors in the division of labor by sex: A cross-cultural analysis. Ethnology, 12(2), 203-225. 
Nadel, D., Weiss, E., Simchoni, O., Tsatskin, A., Danin, A., \& Kislev, M. E. (2004). Stone Age hut in Israel yields world's oldest evidence of bedding. Proceedings of the National Academy of Sciences of the United States of America, 101(17), 6821-6826.

Olausson, D. J. (2008). Does practice make perfect? Craft expertise as a factor in aggrandizer strategies. Journal of Archaeological Method and Theory, 15(1), 28-50.

Olive, M., \& Morgenstern, M. (2004). L'organisation de l'espace habité. In N. Pigeot (Ed.), Les derniers Magdaléniens d'Étiolles: Perspectives culturelles et paléohistoriques, l'unité d'habitation Q31 (pp. 181-220). Paris: Éditions CNRS.

Owen, L. R. (2005). Distorting the past: Gender and the division of labor in the European Palaeolithic. Tübingen, Germany: Kerns Verlag.

Pelegrin, J. (2007). Réflexion sur la notion de "spécialiste" dans la taille de la pierre au Paléolithique. In R. Desbrosse \& A. Thévenin (Eds.), Des grottes de Châtelperron au musée des Antiquités nationales: Hommage à Henri Delporte (pp. 315-318). Paris: Comité des Travaux historiques et scientifiques.

Péré-Noguès, S. (2008). Recherches autour des "marqueurs funéraires" à travers l'exemple de quelques sépultures féminines de la nécropole du Fusco (Syracuse). Pallas: Revue D’histoire Antique, 2008, 151-171.

Petersen, E. B. (1975). A survey of the late Paleolithic and the Mesolithic of Denmark. In S. K. Kozlowsk (Ed.), The Mesolithic in Europe (pp. 77-129). Warsaw: University Press.

Pigeot, N. (1987). Magdaléniens d'Étiolles: Économie du débitage et organisation sociale (l'unité d'habitation U5). Supplément À Gallia préhistoire, 25, 9-157.

Pigeot, N. (2010). Éléments d'une organisation sociale magdalénienne à Étiolles: Du savoirfaire au statut social des personnes. In E. B. W. Zubrow, F. Audouze, \& J. G. Enloe (Eds.), The Magdalenian household: Unraveling domesticity (pp. 198-212). Albany, NY: State University of New York Press.

Piperno, D. R., Weiss, E., Holst, I., \& Nadel, D. (2004). Processing of wild cereal grains in the Upper Palaeolithic revealed by starch grain analysis. Nature, 430(7000), 670-673.

Price, T. D., \& Brown, J. A. (Eds.). (1985). Prehistoric hunter-gatherers: The emergence of cultural complexity. New York: Academic Press.

Reinach, S. (1903). Lart et la magie à propos des peintures et des gravures de l'Âge du Renne. Anthropologie, XIV, 257-266.

Riel-Salvatore, J., \& Gravel-Miguel, C. (2013). Upper Paleolithic mortuary pratices in Eurasia: A critical look at the burial record. In S. Tarlow \& L. N. Stutz (Eds.), The Oxford handbook of the archaeology of death and burial (pp. 303-346). Oxford, UK: Oxford University Press.

Robb,J.E. (1998). The interpretation of skeletal muscle sites: A statistical approach. International Journal of Osteoarchaeology, 8(5), 363-377.

Ruff, C. B. (1987). Sexual dimorphism in human lower limb bone structure: Relationship to subsistence strategy and sexual division of labor. Journal of Human Evolution, 16(5), 391-416.

Sahlins, M. (1972). Stone Age economics. London: Tavistock.

Sassaman, K. E. (1998). Lithic technology and the hunter-gatherer sexual division of labour. In K. A. Hays-Gilpin \& D. S. Whitley (Eds.), Reader in gender archaeology (pp. 159-171). London: Routledge.

Schick, K. D., \& Clark, J. D. (2003). Biface technological development and variability in the Acheulean industrial complex in the Middle Awash region of the Afar Rift, Ethiopia. In M. Soressi \& H. L. Dibble (Eds.), Multiple approaches to the study of bifacial technologies (pp. 1-29). Philadelphia, PA: University of Pennsylvania, Museum of Archaeology and Anthropology. 
404 Squeezing Minds From Stones

Service, E. R. (1966). The hunters. Englewood Cliffs, NJ: Prentice-Hall.

Sigaut, F. (2009). Propos contre-révolutionnaires sur le Néolithique, l'agriculture, etc. In J.-P. Demoule (Ed.), La révolution néolithique dans le monde (pp. 181-196). Paris: Éditions CNRS.

Sillitoe, P., \& Hardy, K. (2003). Living lithics: Ethnoarchaeology in Highland Papua New Guinea. Antiquity, 77(297), 555-566.

Sládek, V., Ruff, C. B., Berner, M., Holt, B. M., Niskanen, M., Schuplerová, E., \& Hora, M. (2016). The impact of subsistence changes on humeral bilateral asymmetry in Terminal Pleistocene and Holocene Europe. Journal of Human Evolution, 92, 37-49.

Snow, D. R. (2013). Sexual dimorphism in European Upper Paleolithic cave art. American Antiquity, 78(4), 746-761.

Soffer, O. (1985). Patterns of intensification as seen from the Upper Paleolithic of the Central Russian plain. In T. D. Price \& J. A. Brown (Eds.), Prehistoric hunter-gatherers: The emergence of cultural complexity (pp. 235-270). New York: Academic Press.

Soffer, O., Adovasio, J. M., \& Hyland, D. C. (2002). Perishable technologies and invisible people: Nets, baskets, and "Venus" wear ca. 26,000 BP. In B. A. Purdy (Ed.), Enduring records: The environmental and cultural heritage of wetlands (pp. 233-245). Oxford, UK: Oxbow Press.

Sparacello, V. S., Villotte, S., Shackelford, L. L., \& Trinkaus, E. (2016). Patterns of humeral asymmetry among Late Pleistocene humans. Comptes rendus Palevol, 16(5/6), 680-689.

Sterling, K. (2014). Man the hunter, woman the gatherer? The impact of gender studies on hunter-gatherer research (a retrospective). In V. Cummings, P. Jordan, \& M. Zvelebil (Eds.), The Oxford handbook of the archaeology and anthropology of hunter-gatherers (pp. 151-173). Oxford, UK: Oxford University Press.

Testart, A. (1982). Les chasseurs-cueilleurs ou l'origine des inégalités. Paris: Société d'Ethnologie.

Testart, A. (1985). Le communisme primitif. Paris: Éditions de la Maison des Sciences de l'Homme.

Testart, A. (1986). Essai sur les fondements de la division sexuelle du travail chez les chasseurscueilleurs. Paris: Éditions de l'EHESS.

Testart, A. (2005). Éléments de classification des sociétés. Paris: Errance.

Testart, A. (2012). Avant l'histoire: L'évolution des sociétés, de Lascaux à Carnac. Paris: Gallimard.

Thomas, A. (2014). Bioarchaeology of the Middle Neolithic: Evidence for archery among early European farmers. American Journal of Physical Anthropology, 154(2), 279-290.

Tiger, L. (1969). Men in groups. New York: Random House.

Tostevin, G. B. (2012). Seeing lithics: A middle-range theory for testing for cultural transmission in the Pleistocene. Oxford, UK: Oxbow Books.

Trinkaus, E., Buzhilova, A. P., Mednikova, M. B., \& Dobrovolskaya, M. V. (2014). The people of Sunghir: Burials, bodies and behavior in the Earlier Upper Paleolithic. New York: Oxford University Press.

Trinkaus, E., Buzhilova, A. P., Mednikova, M. B., \& Dobrovolskaya, M. V. (2015). The age of the Sunghir Upper Paleolithic human burials. Anthropologie (Brno), 53(1-2), 221-231.

Turnbull, C. M. (1965). Wayward servants: The two worlds of the African Pygmies. Garden City, NY: Natural History Press.

Vanhaeren, M. (2002). Les fonctions de la parure au Paléolithique supérieur: De l'individu à l'unité culturelle. Doctoral thesis, Université Bordeaux I, Bordeaux, France.

Vanhaeren, M., \& d'Errico, F. (2001). La parure de l'enfant de La Madeleine (fouilles Peyrony): Un nouveau regard sur l'enfance au Paléolithique supérieur. Paléo, 13, 201-237. 
Vanhaeren, M., \& d'Errico, F. (2003). Le mobilier funéraire de la Dame de Saint-Germain-laRivière (Gironde) et l'origine paléolithique des inégalités. Paléo, 15, 195-238.

Vieugué, J. (2012). Spécialisation fonctionnelle des premières productions céramiques dans les Balkans (6100-5500 av. J.-C.). Bulletin de La Société Préhistorique Française, 2012, 251-265.

Villotte, S., Brůžek, J., \& Henry-Gambier, D. (2011). Caractéristiques biologiques des sujets adultes gravettiens: Révision de l'âge au décès et du sexe. In N. Goutas, L. Klaric, D. Pesesse, \& P. Guillermin (Eds.), À la recherche des identités gravettiennes: Actualités, questionnements et perspectives: Actes de la table ronde sur le Gravettien en France et dans les pays limitrophes (pp. 209-216). Paris: Mémoires de la Société préhistorique française.

Villotte, S., Churchill, S. E., Dutour, O. J., \& Henry-Gambier, D. (2010). Subsistence activities and the sexual division of labor in the European Upper Paleolithic and Mesolithic: Evidence from upper limb enthesopathies. Journal of Human Evolution, 59(1), 35-43.

Villotte, S., \& Knüsel, C. J. (2014). “I sing of arms and of a man . . .”: Medial epicondylosis and the sexual division of labour in prehistoric Europe. Journal of Archaeological Science, 43, $168-174$.

Wadley, L. (1998). The invisible meat providers: Women in the Stone Age of South Africa. In S. Kent (Ed.), Gender in African prehistory (pp. 69-81). London: SAGE.

Waguespack, N. M. (2005). The organization of male and female labor in foraging societies: Implications for Early Paleoindian archaeology. American Anthropologist, 107(4), 666-676.

Washburn, S. L., \& Lancaster, C. S. (1968). The evolution of hunting. In R. B. Lee \& I. DeVore (Eds.), Man the hunter: The first intensive survey of a single, crucial stage of human development_Man's once universal hunting way of life (pp. 293-303). Chicago, IL: Aldine Transaction.

Weedman, K. (2005). Gender and stone tools: An ethnographic study of the Konso and Gamo hideworkers of southern Ethiopia. In L. Frink \& K. Weedman (Eds.), Gender and hide production (pp. 175-196). Walnut Creek, CA: Altamira Press.

Weedman, K. (2006). Gender and ethnoarchaeology. In S. M. Nelson (Ed.), Handbook of gender archaeology (pp. 247-294). Walnut Creek, CA: Altamira Press.

Weiss, E., Kislev, M. E., Simchoni, O., Nadel, D., \& Tschauner, H. (2008). Plant-food preparation area on an Upper Paleolithic brush hut floor at Ohalo II, Israel. Journal of Archaeological Science, 35(7), 2400-2414.

White, R. (1999). Intégrer la complexité sociale et opérationnelle: La construction matérielle de l'identité sociale à Sungir. In H. Camps-Fabrer \& M. Julien (Eds.), Préhistoire d'os: Recueil d'études sur l'industrie osseuse préhistorique (pp. 319-331). Aix-en-Provence: Publications de l'Université de Provence.

White, R. (2006). Looking for biological meaning in cave art. American Scientist, 94(4), 371-372.

Woodburn, J. (1982). Egaliarian societies. Man, New Series, 17(3), 431-451.

Zihlman, A. L. (1998). Woman the gatherer: The role of women in early hominid evolution. In K. A. Hays-Gilpin \& D. S. Whitley (Eds.), Reader in gender archaeology (pp. 91-105). London: Routledge.

Zihlman, A. L. (2013). Engendering human evolution. In D. Bolger (Ed.), A companion to gender prehistory (pp. 23-44). Chichester, UK: Wiley-Blackwell. 